\title{
ISOLATION AND IDENTIFICATION OF SOME GRAM-NEGATIVE BACTERIA FROM COCKROACHES COLLECTED FROM HOSPITAL, RESTAURANT AND SLUM AREAS OF DHAKA CITY, BANGLADESH
}

\author{
Akter, T., S. Ahmed ${ }^{1}$ and R. Biswas \\ Department of Zoology, University of Dhaka, Dhaka-1000, Bangladesh; ${ }^{1}$ Department of Microbiology, \\ University of Dhaka, Dhaka-1000, Bangladesh
}

\begin{abstract}
The study was conducted to identify the bacteriological quality from different species of cockroaches in three study areas in Dhaka city. A total of 15 cockroaches was collected from three different selected study areas, viz. Penang Restaurant of Bakshi Bazar, Sir Salimullah Medical College Mitford Hospital and Urban slum of Kamalapur, Dhaka. Using detection keys, the cockroaches were identified as Periplaneta americana (53.33\%), Blatella germanica (40\%) and Blatta orientalis (6.67\%). All of 15 cockroaches were used to isolate bacteria from external body surface and alimentary tract. A total of 48 isolates was obtained from these three species of cockroaches. Out of them $29(60.42 \%)$ isolates were obtained from P. americana, $17(35.42 \%)$ from B. germanica, and $2(4.16 \%)$ from B. orientalis. Three Gram negative bacteria, viz. Klebsiella sp., Escherichia coli and Pseudomonas sp. were isolated from alimentary canal and external surface. On the external body surface $71.43 \%$ isolates were E. coli, $21.43 \%$ were Pseudomonas sp. and $7.14 \%$ were Klebsilella sp. In case of alimentary tract, $55.89 \%$ isolates were Pseudomonas sp., $23.52 \%$ were E. coli, and the rest $20.59 \%$ were Klebsiella sp. Comparison between study areas showed that the food handling area yielded maximum number $(41.67 \%)$ of isolates and the urban slum yielded minimum number $(25 \%)$ of isolates. In food handling isolates, $45 \%$ were Klebsiella, whereas E. coli and Pseudomonas sp. were $40 \%$ and $15 \%$, respectively. In Hospital, E. coli was the most common (50\%), followed by Klebsiella (37.5\%) and Pseudomona sp. (12.50\%). In urban slum, $41.67 \%$ isolates were Klebsiella sp., $41.67 \%$ were Pseudomonas sp. and $16.66 \%$ were E. coli. This study shows that cockroaches carry several Gram-negative bacteria on their body surface and alimentary tract and play a role in bacterial transmission to human.
\end{abstract}

Key words: Cockroaches, Gram-negative bacteria, Isolation, Dhaka City.

\section{INTRODUCTION}

Cockroaches are among the most notorious pests of premises, which not only contaminate food by leaving the droppings and bacteria that can cause food poisoning, but also they transmit bacteria, fungi and other pathogenic microorganisms in infested areas (Czajka et al. 2003, Salehzadeh et al. 2007). Two most significant pest cockroaches universal as well as in Bangladesh are the German cockroach (Blatella germanica) and the American cockroach (Periplaneta americana). The German cockroach is more common inside homes particularly in kitchens while the later is found around the home close to water pipes and drainage systems (Akbari et al. 2014). They live close to human dwellings and are important carriers of etiological agents belonging to all groups of potential pathogens: viral, bacterial, protozoan and helminthes (Agbodaze and Owusu 1989, Fotedar et al. 1991, Cloarec et al. 1992, Pai et al. 2003). Numerous pathogens counting 32 species of bacteria (including Salmonella and Shigella species), 15 species of fungi and moulds, seven helminths (intestinal parasites), two protozoans, and one virus were found in or on cockroaches or in their feces (Pai et al. 2005, Zarchi and Vatani 2009). In Bangladesh, Salmonella, Shigella, S. aureus, B. cereus, and E. coli were isolated from cockroaches (Paul et al. 1992).

Periplaneta americana harbored more bacteria species than B. germanica (Rivault et al. 1993, Prado et al. 2006, Pai et al. 2003). The range of problems caused by the presence of cockroaches varies between hospitals, food-handling establishments, public institutions, and multi-family dwellings (Rivault et al. 1993). In hospitals, it was found that cockroaches can act as potential vectors in the epidemiology of nosocomial infections, especially in the transmission of drug-resistant bacteria (Fotedar 
et al. 1991, Cotton et al. 2000). Escherichia coli, Pseudomonas aeruginosa, Klebsiella sp. and several other potential pathogens were isolated from cockroaches collected from hospitals (Guyader et al. 1989, Oothuman et al. 1989).

The role of cockroaches as mechanical vectors and reservoir for pathogens and their drug resistance is unknown. The goal of this study was to isolate and identify Gram negative pathogenic bacteria associated with guts and cuticle of the cockroaches in the selected areas by using classical microbiological methods.

\section{Sample collection site}

\section{MATERIAL AND METHODS}

The present study was conducted in Entomology Laboratory, Department of Zoology and Microbiology Laboratory, Department of Microbiology, University of Dhaka. For the collection of cockroaches three selective locations were chosen. The locations were Penang Restaurant of Bakshi Bazar, Sir Salimullah Medical College Mitford Hospital (SSMCMH) and Kamalapur slum at Dhaka, Bangladesh.

\section{Cockroach collections}

Cockroaches were collected from the study areas with traps and hand picking. The trap was made with disposal plastic bottles and lures. For microbial investigation, cockroaches were collected using sterile screw-capped $250 \mathrm{ml}$ jars and sterile hand-gloves following Paul et al. (1992). The collected cockroaches were placed into the sterile tubes individually. The tubes were transferred to the lab immediately after capturing and were killed using chloroform. The cockroaches were identified according to Kabir et al. (1981).

\section{Bacteriological analysis of the cockroaches}

The external body surface of the collected cockroaches was washed with vortexing in $10 \mathrm{ml}$ sterile physiological saline for two minutes and the wash was taken as external body homogenate sample. After external body washing, the cockroaches were soaked in $90 \%$ ethanol for five minutes to decontaminate their external surface and dried, followed by washing with sterile saline to remove traces of ethanol. The alimentary tract of cockroaches was aseptically dissected out using autoclaved-sterilized entomological dissecting needles under a dissecting microscope. The instrument was dipped in ethanol and flamed between dissections. The excised gut was homogenized in $10 \mathrm{ml}$ of sterile normal saline water following Tachbele et al. (2006).

A total of 15 cockroaches, five from each site, containing 30 samples (15 external body surface and 15 gut homogenates) was analyzed. The samples were tested for the presence of common enteric Gram negative pathogens, for this purpose one loop full homogenate sample was cultured onto MacConkey agar medium by using streak plate technique, followed by incubation at $37^{\circ} \mathrm{C}$ for 24 hours. Growth on all plates was observed and the characteristics of the isolate colonies were noted. To obtain pure culture, isolated colonies from the selective medium were sub-cultured on Nutrient agar (NA) medium.

\section{Identification of bacterial isolates by biochemical tests}

The identification of the bacterial isolates was done by performing Gram staining and biochemical tests. Gram staining was performed to determine the size, shape, arrangement, and Gram reaction of the isolated organisms. The steps were followed as described by Pelczar et al. (1993).The test included Citrate utilization test, Catalase test, Motility test, Urease test, Indole test and Kligler's Iron Agar test. All the tests were performed according to the standard protocol as described in Bergey's Manual of Systematic Bacteriology (Garrity 2001). The isolates that were presumptively identified as E. coli were 
grown on Eosine Methylene Blue (EMB) agar, which is a selective medium for E. coli, where E. coli gives their characteristic metallic sheen. Similarly, Pseudomonas sp. was further grown on Cetrimide agar, the selective medium for this bacterium.

\section{RESULTS AND DISCUSSION}

Periplaneta americana was the most common species in all of the study areas $(53.33 \%)$, followed by B. germanica $(40.00 \%)$ and B. orientalis $(6.67 \%)$ (Table 1). This result indicates that these three species of cockroaches were the most active in the study areas and this result is consistent with the findings of Pai et al. (2005) in some selected areas in China. Fifty percent Periplaneta americana were found in Penang restaurant, $12.50 \%$ in SSMCMH and $37.50 \%$ in Urban slum, Kamalapur. B. germanica were only found in SSMCMH (66.67\%) and Urban slum, Kamalapur (33.33\%); while B. orientalis were found only in Penang restaurant (Table 1)

Table 1. Percentage of total cockroaches collected from the study areas.

\begin{tabular}{|c|c|c|c|c|}
\hline Study area & Periplaneta americana & Blatella germanica & Blatta orientalis & Total $(\%)$ \\
\hline Penang Restaurant, Bakshi Bazar & 4 & 0 & 1 & $5(33.33)$ \\
\hline Sir Salimullah Medical College Hospital & 1 & 4 & 0 & $5(33.33)$ \\
\hline Urban Slum, Kamalapur & 3 & 2 & 0 & $5(33.33)$ \\
\hline
\end{tabular}

The numbers of bacterial isolates collected from Penang restaurant were 20 (seven from external body surface and 13 from gut), 16 from SSMCH (five from external body surface and 11 from gut) and 12 from Urban slum, Kamalapur (two from external body surface and 10 from gut). The total number of bacterial isolates collected from $P$. americana was 29 (nine from external body surface and 20 from gut), 17 from $B$. germanica (five from external body surface and 12 from gut) and 2 from $B$. orientalis only (found only from gut) (Table 2). No growth found in the samples of external body surface homogenate samples of any of the cockroaches.

Table 2. Distribution of the isolate colonies.

\begin{tabular}{|c|c|c|c|c|c|c|c|}
\hline \multirow[t]{2}{*}{ Study area } & \multicolumn{2}{|c|}{ Periplaneta americana } & \multicolumn{2}{|c|}{ Blatella germanica } & \multicolumn{2}{|c|}{ Blatta orientalis } & \multirow[t]{2}{*}{ Total (\%) } \\
\hline & $\begin{array}{c}\text { External } \\
\text { surface }\end{array}$ & Guts & $\begin{array}{c}\text { External } \\
\text { surface }\end{array}$ & Guts & $\begin{array}{l}\text { External } \\
\text { surface }\end{array}$ & Guts & \\
\hline Penang restaurant & $\begin{array}{c}\mathrm{C}:(14-20) \\
=7\end{array}$ & $\begin{aligned} \mathrm{C}: & (1-11) \\
& =11\end{aligned}$ & 0 & 0 & 0 & $\begin{array}{c}\mathrm{C}:(12-13) \\
=2\end{array}$ & $20(41.67)$ \\
\hline SSMCMH & $\begin{aligned} \text { C: } 32 \\
=1\end{aligned}$ & $\begin{array}{c}C:(21-23) \\
=3\end{array}$ & $\begin{array}{c}C: \begin{array}{c}(33-36) \\
=4\end{array}\end{array}$ & $\begin{array}{c}C: \begin{array}{c}(24-31) \\
=8\end{array}\end{array}$ & 0 & 0 & $16(33.33)$ \\
\hline Urban slum, Kamalapur & $\begin{aligned} C & : 47 \\
& =1\end{aligned}$ & $\begin{array}{c}C:(37-42) \\
=6\end{array}$ & $\begin{aligned} \mathrm{C}: 48 \\
=1\end{aligned}$ & $\begin{array}{c}\mathrm{C}:(43-46) \\
=4\end{array}$ & 0 & 0 & $12(25.00)$ \\
\hline Total & 9 & 20 & 5 & 12 & 0 & 2 & 48 \\
\hline Grand Total (\%) & \multicolumn{2}{|c|}{$29(60.42)$} & \multicolumn{2}{|c|}{$17(35.42)$} & \multicolumn{2}{|c|}{$2(10)$} & $48(100)$ \\
\hline
\end{tabular}

Microscopic examination of the isolates after Gram staining showed that all the isolates were Gram negative rods (Fig. 1 and 2). The Gram negative isolates were identified in different biochemical tests which are summarized in Table 3. Fakoorziba et al. (2010) isolated around 25 species of medically important bacteria from $P$. americana and B. germanica, of which at least 22 were Gram negative. 


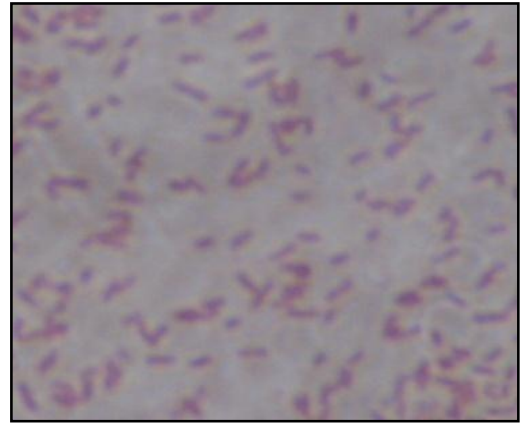

a

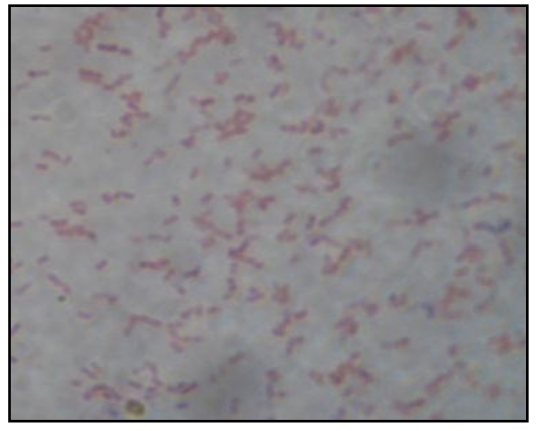

b

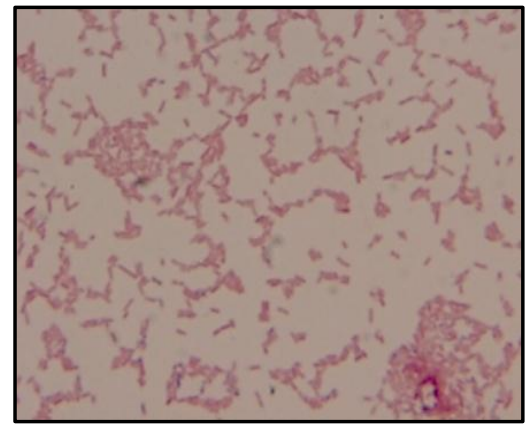

C

Fig. 1. Microscopic observation: a. E. coli, b. Klebsiella and c. Pseudomonas.

Based on the biochemical tests and growth on selective media it was found that out of 48 isolates, 20 (41.67\%) isolates were Klebsiella sp., 18 (37.50\%) and 10 (20.83\%) isolates were E. coli and Pseudomonas sp., respectively. Wannigma et al. (2014) reported that the main bacteria on cockroaches were Klebsiella pneumoniae, Escherichia coli, Enterobacter aerogenes and Pseudomonas aeruginosa.

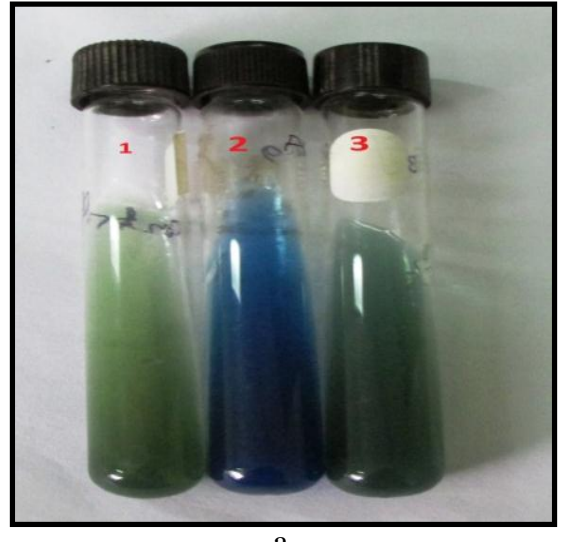

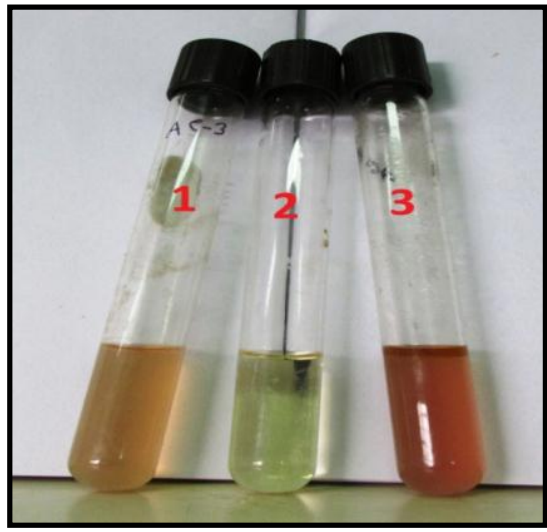

b

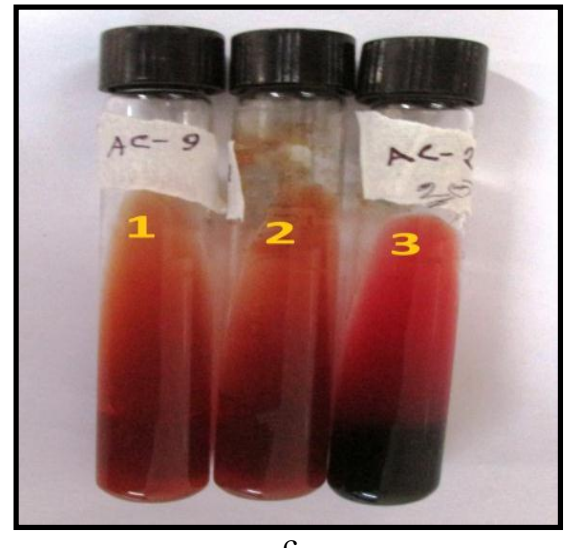

c

Fig. 2. Biochemical tests used for the identification of isolates: a. Citrate utilization test; b. Indole production test and c. Kligler's Iron Agar test.

Table 3. Biochemical test results of different isolates

\begin{tabular}{|c|c|c|c|c|c|c|c|c|c|c|}
\hline \multirow[t]{2}{*}{ Study area } & \multirow[t]{2}{*}{ Isolate number } & \multicolumn{8}{|c|}{ Biochemical test } & \multirow{2}{*}{$\begin{array}{l}\text { Presumptive } \\
\text { identification }\end{array}$} \\
\hline & & 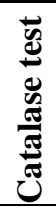 & 芯 & 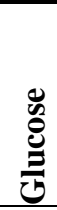 & త్ర & $\tilde{\mathbb{Z}}$ & 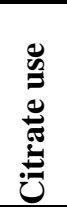 & 总 & 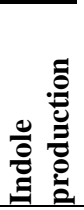 & \\
\hline \multirow{3}{*}{ Penang restaurant } & C- $1,2,3,4,5,8,9,10,18$ & + & - & + & + & - & + & + & - & Klebsiella sp. \\
\hline & C- $6,7,11,12,14,15,16,17$ & + & + & + & + & - & - & - & + & E. coli \\
\hline & C- $13,19,20$ & + & - & - & - & - & + & - & - & Pseudomonas sp. \\
\hline \multirow{3}{*}{ SSMCMH } & $\mathrm{C}-22,23,24,25,26,27$ & + & - & + & + & - & + & + & - & Klebsiella sp. \\
\hline & C- $21,28,30,32,33,34,35,36$ & + & + & + & + & - & - & - & + & E. coli \\
\hline & C-29,31 & + & - & - & - & - & + & - & - & Pseudomonas sp. \\
\hline \multirow{3}{*}{ Slum, Kamalapur } & C-39,40,42,45,46 & + & - & + & + & - & + & + & - & Klebsiella sp. \\
\hline & C- 47,44 & + & + & + & + & _- & - & - & + & E. coli \\
\hline & C- $37,38,41,43,48$ & + & - & - & - & - & + & - & - & Pseudomonas sp. \\
\hline
\end{tabular}

From the total isolates the largest percent $(41.67 \%)$ of isolates were collected from the cockroaches of the Penang restaurant. The Urban slum cockroaches possessed the lowest percentage (25\%) of all 
isolates. The cockroaches from the SSMCMH contained $33.33 \%$ isolates. In case of restaurant the most dominant isolated bacteria was Klebsiella sp. (45\%) and the least dominant was Pseudomonas sp. $(15 \%)$. But in case of hospital the most dominant isolated bacteria was E. coli $(50 \%)$ and least dominant was Pseudomonas sp. (12.5\%). On the other hand, Klebsiella sp. and Pseudomonas sp. were dominant (41.67\%) bacterial isolates and the least dominant was E. coli in urban slum areas (Table 4). The findings of pathogenic isolates in the cockroaches collected from hospital is consistent with the findings of Zarchi and Vatani (2009) who detected E. coli and Pseudomonas sp. as the most isolated bacteria from the hospital cockroaches.

Table 3. Distribution of pathogens isolated from three different areas.

\begin{tabular}{lcccc}
\hline Study area & Klebsiella sp. & E. coli & Pseudomonas sp. & Total (\%) \\
\hline Penang restaurant & $9(45 \%)$ & $8(40 \%)$ & $3(15 \%)$ & $20(41.67 \%)$ \\
SSMCMH & $6(37.50 \%)$ & $8(50 \%)$ & $2(12.50 \%)$ & $16(33.33 \%)$ \\
Slum, Kamalapur & $5(41.67 \%)$ & $2(16.66 \%)$ & $5(41.67 \%)$ & $12(25 \%)$ \\
\hline Total (\%) & $20(41.67)$ & $18(33.33 \%)$ & $10(20.83 \%)$ & $48(100 \%)$ \\
\hline
\end{tabular}

From the isolates of external body surface E. coli was $71.43 \%$, whereas Pseudomonas sp. and Klebsiella sp. was $21.43 \%$ and $7.14 \%$, respectively. From the gut isolates the highest $55.89 \%$ was Pseudomonas sp., whereas $23.52 \%$ and $20.59 \%$ was E. coli and Klebsiella sp., respectively (Fig. 3). In case of external body surface the same results were obtained by Vahabi et al. (2007) who reported that E. coli was the most frequent extracted bacterium from cockroach's body surface in Iran.

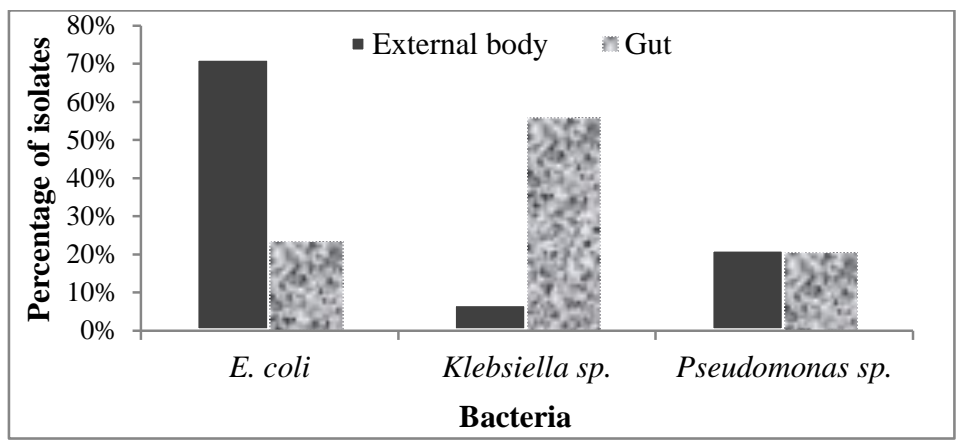

Fig. 3. Percentage of different isolates in external surface and gut.

The isolation of E. coli, Klebsiella sp. and Pseudomonas sp. from the cockroach indicated that domestic pests could cause health problem to humans, as these are potential pathogen. The presence of cockroaches in human dwelling areas is never desirable and must be taken into consideration.

\section{REFERENCES}

Akbari, S., M. A. Oshaghi, S. S. H. Aghdam, S. Hajikhani, G. Oshaghi and M. H. Shirazi. 2014. Aerobic Bacterial Community of American Cockroach- Periplanata americana Step toward finding suitable Paratransgenesis candidates. J. Arthropod-Borne Dis. 9(1): 35-48.

Agbodaze, D. and S. B. Owusu. 1989. Cockroaches (Periplanata americana) as carriers of bacterial diarrhea in Acra, Ghana. Cent. Afr. J. Med. 35: 484-486.

Cloarec, A., C. Rivault, F. Fontaine and L. A. Guyader. 1992. Cockroaches as carriers of bacteria in multi-family dwellings. Epidemiol. Infect. 109: 483-490.

Czajka, E., K. Pancer, M. Kochman, A. Gliniewicz, B. Sawicka, D. Rabczenko and M. H. Stypulkowska. 2003. Characteristics of bacteria isolated from body surface of German cockroaches caught in hospitals. Przegl. Epidemiol. 57: 655-662. 
Cotton, M. F., E. Wasserman, C. H. Pieper, D. C. Theron, D. V. Tubbergh, G. Campbell, F. C. Fang and J. Barnes. 2000. Invasive disease due to extended spectrum beta-lactamase-producing Klebshiella pneumoniae in a neonatal unit: the possible role of cockroaches. J. Hosp. Infect. 44: 13-17.

Fakoorziba, M. R., F. Eghbal, J. Hassanzadeh and M. D. Moemenbellahfard. 2010. Cockroaches (Periplaneta americana and Blattella germanica) as potential vectors of the pathogenic bacteria found in nosocomial infections. Ann. Trop. Med. Parasitol. 104(8): 521-528.

Fotedar, R., S. U. Banerjee and A. Verma. 1991. Cockroaches as (Blattella germanica) as carriers of microorganisms of medical importance in hospitals. Epidemiol. Infect. 107: 181-187.

Garrity G. M., D. R. Boone and R. W. Castenholz. 2001. Bergey's Manual of Systematic Bacteriology. Vol. 1. Springer-Verlag, New York. 722 pp.

Guyader, L. A., C. Rivault and J. Chaperon. 1989. Microbial organisms carried by brown-banded cockroaches in relation to their spatial distribution in a hospital. Epidemiol. Infect. 102(3): 485-492.

Kabir, S. H. M., M. A. Quayum and K. M. N. Huda. 1981. A textbook of Zoology for Higher Secondary Class. S. M. H. Kabir Publisher, 20-G, Dhaka, Bangladesh.

Oothuman, P., J. Jefferry, A. H. Aziz, A. E. Bakar and M. Jegathesan. 1989. Bacterial pathogens isolated from cockroaches trapped from pediatrics wards in peninsular Malaysia. Trans. R. Soc. Trop. Med. Hyg. 83(1): 133-135.

Pai, H. H., W. C. Chen and C. F. Peng. 2003. Isolation of non-tuberculous mycobacteria from hospital cockroaches (Periplanata americana). Journal of Hospital infection. 53: 224-228.

Pai, H. H., W. C. Chen and C. F. Peng. 2005. Isolation of bacteria with antibiotic resistance from household cockroaches (Periplanata americana and Blattella germanica). Acta Trop. 93(3): 259-265.

Paul, S., A. M. Khan and M. Muhibullah. 1992. Evaluation of the common cockroach Periplanata americana as carrier of medically important bacteria. J. Communi. Dis. 24: 206-210.

Pelczar, M. J., E. C. S. Chan and N. R. Krieg. 1993. Microbiology: Concept and Applications. McGraw-Hill, New York, USA. 896 pp.

Prado, M. A., E. Gir, M. S. Pereira, C. Reis and F. C. Pimenta. 2006. Profile of Antimicrobial Resistance of Bacteria Isolated from Cockroaches (Periplaneta americana) in a Brazilian Health Care Institution. Braz. J. Infect. Dis. 10(1): 26- 32.

Rivault, C., A. Cloarec and L. A. Guyader. 1993. Bacterial load of cockroaches in relation to urban environment. Epidemiol. Infect. 110: 317-325.

Salehzadeh, A., P. Tavacol and H. Mahjub. 2007. Bacterial, fungal and parasitic contamination of cockroaches in public hospitals of Hamadan, Iran. J. Vect. Borne Dis. 44: 105-110.

Tachbele, E., W. Erku, T. Gebre-Michael and M. Ashenafi. 2006. Cockroach-associated food-borne bacterial pathogens from some hospitals and restaurants in Addis Ababa, Ethiopia: Distribution and antibiograms. $J$. Rural Trop. Publ. Health. 5: 34-41.

Vahabi, A., J. Rafinejad, P. Mohammadi and F. Biglarian. 2007. Regional evaluation of bacterial contamination in hospital environment cockroaches. Iran J. Environ. Health Sci. Eng. 4(1): 57-60.

Wannigama, D. L., R. Dwivedi and A. Z. Ramazani. 2014. Prevalence and Antibiotic Resistance of GramNegative Pathogenic Bacteria Species Isolated from Periplaneta americana and Blattella germanica in Varanasi, India. J. Arthropod-Borne Dis. 8(1): 10-20.

Zarchi, A. A. and H. Vatani. 2009. A survey on species and prevalence rate of bacterial agents isolated from cockroaches in three hospitals. Vector Borne Zoonotic Dis. 9(2): 197-200. 